\title{
Narration in Technical Communication
}

\author{
Ben F. Barton \\ University of Michigan \\ Marthalee S. Barton \\ University of Michigan
}

Non-literary texts are being interpreted and studied as narratives to great ad-
vantage in many, diverse fields. In contrast, narration is widely devalued
among teachers and researchers of technical communication. This devalua-
tion is unwarranted in light of the complexity, pervasiveness, and potential
power of narration in technical communication. Research into narration as a
focal topic may facilitate a fuller, more conscious exploitation of the narrative
mode.

National Underwriter magazine reports the following story (qtd. in Peters and Waterman 55): A St. Louis client of an automobileinsurance company was repeatedly billed by the firm's computer for $\$ 0.00$. Perhaps reasoning that "nothing was required in return," the client did nothing, becoming alarmed only on receipt of a "final notice" threatening to cancel his policy. He then called his agent, who decided the best course of action was not to send a letter articulating the reasons for non-payment but, instead, to forward a check for $\$ 0.00$. The client complied and was soon rewarded with a thank-you note acknowledging the payment and assuring him that the policy would be continued.

As our topic is narration in technical communication, you may forgive our opening with a story. Clearly, the story can be read as portraying bureaucratic incompetency or the victimization of the public by technology run amok, or even as a testimonial to professional ingenuity. It can also be read, however, as a meta-narrative, a narrative about the nature of narrative. Specifically, it illustrates the power of the narrative over the rational or logical mode of discourse in certain contexts: The agent's solution works because it addresses and fulfills narrative, as opposed to logical, exigencies; that is, the story evades the demands of logic by recreating a mechanical world where the client's "empty" gesture is the appropriate response to "hollow" demands.

But, in extolling the virtues of narration, we're getting ahead of our story. For while we ultimately hope to interest you in research into narrative in technical communication, we first want to illustrate that non-literary texts are being interpreted and studied as narrative to great advantage in many, diverse fields. We then claim that, in contrast, narration is widely devalued as a mode of discourse, among teachers and researchers of technical communication. After that, we show that such devaluation is unwarranted by suggesting the complexity, pervasiveness, and potential advantages of narration in technical communication. 


\section{The Rise of Multidisciplinary Studies of Narration}

Why should we, as researchers, look at narration as a focal topic in our on-going study of scientific and technical communication? The first reason is a purely formal one: Narration is currently under study by researchers in many and diverse disciplines, but not by those in technical communication. Colloquially put, everyone else is doing it, so why not us? Rephrased in the jargon of narrative theory, our participation in narratological research is required by the exigencies of the current interdisciplinary "master plot."

\section{Narration in Natural Discourse}

Most of us, of course, are uneasy about committing resources based solely on so formal an argument; we may find a more compelling reason for commitment in the impressive claims made for narration in natural discourse. Thus, we read, for example, that narrative is

not to be regarded as an aesthetic invention used by artists to control, manipulate and order experience, but as a primary act of mind transferred to and from life .... For we dream in narrative, daydream in narrative, remember, anticipate, hope, despair, believe, doubt, plan, revise, criticize, construct, gossip, learn, hate, and love by narrative (Hardy 5).

In short, "[m]an is in his actions and practice ... essentially a story-telling animal" (MacIntyre 201). Roland Barthes would agree: "[Narrative] is simply there, like life itself ... international, transhistorical, transcultural" (79).

These are powerful claims indeed, too powerful for some to endorse without reservation. For as Sartre's Roquentin learned, life has no beginnings, middles, and ends; such narrative shape is, rather, imposed after the fact to make sense of otherwise inchoate experiences. That is, stories are, as Louis Mink notes, "not lived but told" (123). But even if narratives are not primary in life, Mink believes, and most narrative theorists would agree, that narrative acts are primary in discourse and are not, as in the lay view, "imperfect substitutes for more sophisticated forms of explanation and understanding" or "the unreflective first steps along the road which leads toward the goal of scientific or philosophical knowledge" (123). In short, despite some contention among theorists, the claim of narration as primary in natural discourse remains, and the claim is impressive.

\section{Narration in Specialized Discourse}

Turning from natural discourse to the specialized discourses of academic disciplines, we find corroborating claims for the primacy of narration. An interest in narrative in literary studies is hardly surprising, but growing recognition of its primacy may be. Much of the exciting recent research in literary studies has, in fact, been in narrative theory; its proliferation and success are attested symbolically by the emergence of the term "narratology," the study of the structure 
and function of narrative. We refer to the work of Gérard Genette, Roland Barthes, Barbara Herrnstein Smith, Gerald Prince, Mieke $\mathrm{Bal}$, and Frank Kermode, among many others.

Even more surprising, though, is literary theorist Jonathan Culler's observation that some of the most fruitful insights into literary narrative have been byproducts of studies of non-literary texts by scholars outside the field of literature ("Problems"). However accurate Culler's ironic assessment may be, the fact remains that narrative is viewed as primary in the discourse of many fields outside of literature. Culler states the case in historical discourse: "W. B. Gallie has argued in Philosophy and Historical Understanding that the kind of understanding afforded by history writing involves not grasping causal laws but rather seeing how one thing leads to another as in a story" ("Literary Theory" 214-15). In the field of psychoanalysis, the case for the primacy of narration is made by Roy Schafer:

Psychoanalytic theorists of different persuasions have employed different interpretive principles or codes-one might say different narrative structures-to develop their ways of doing analysis and telling about it*. These narrative structures present or imply two coordinated accounts: one, of the beginning, the course, and the ending of human development; the other, of the course of the psychoanalytic dialogue. Far from being secondary narratives about data, these structures provide primary narratives that establish what is to count as data. Once installed as leading narrative structures, they are taken as certain in order to develop coherent accounts of lives and technical practices. ("Narration" 25-26; ref. is to Schafer "On Becoming")

Peter Brooks corroborates Schafer's assertion of the primacy of narrative in the psychoanalytical process, specifically, in Freud's conduct of the Wolfman case. Brooks finds, for example, that Freud's tracing of the Wolfman's neurosis to a traumatic primal scene at age one and a half was the product of narrative exigencies. Moreover, understanding based on following a story, on perceiving a narrative pattern, has proven fruitful in other fields as well: Witness the use of narrative models for analysis of non-literary texts in sociology by Robert Nisbet, in anthropology by Misia Landau and Victor Turner, in philosophy by Jacques Derrida, in law by Stephen Yeazell, and in economics by Donald McCloskey. And the chorus mounts.

\section{The Unwarranted Devaluation of Narration in Technical Communication}

\section{Disinterest in Narration}

Given the mounting number of voices profitably participating in the multidisciplinary dialogue on narration, what can we say of our contribution? A literature review finds us almost mute on the subject of narration in technical communication. Not surprisingly, our pedagogy reflects similar disinterest: In one of the rare studies of narration in our field, Mary Lay notes that "narrative is usually ex- 
cluded" from "the rhetorical patterns taught in technical writing courses" (158). And, while many technical-communication textbooks treat process description, operating instructions, and progress reports-all "applied narratives," in Lay's view-these textbooks, too, generally omit instruction in narration per se. Similarly, Judith Fishman notes the inattention to narration in the textbooks of a sister field, composition.

\section{Reasons for Devaluation}

What underlies our devaluation of narration in technical communication? The reasons are numerous, some frankly speculative. We may devalue narration because the most obvious cases of it are associated with modes of discourse traditionally underprivileged in the canonical literature of technical communication. Thus, the most obvious cases of narration typically occur in the oral and informal modes of communication-i.e., in relatively devalued modes. Similarly, the most obvious cases of narration in written discourse typically occur in devalued genres. Note, for example, the near scorn accorded popularizations of science, texts that are overtly narrative (Kuhn 344). Recall the clamor in the scientific community attending publication of The Double Helix, James Watson's narrative account of the discovery of the structure of DNA. Editor Gunther Stent's analysis of reviews of the work notes that Watson was widely criticized by scientists for "telling tales out of school," for exposing pettiness, vanity, and opportunism among the "disembodied intellectuals" that traditionally figure in technical literature. Indeed, objections by Francis Crick and Maurice Wilkins, co-recipients of the Nobel Prize, to The Double Helix were so strenuous that the university press of Watson's home campus, Harvard, reneged on its agreement to publish the book.

Equally contributory to the devaluation of narration in our field are the methodological biases characteristic of technical-communication research to date. As we have argued elsewhere, from its inception this research has focused on distinctive, as opposed to shared, features in relation to other discourses ("What is Technical Writing?"). Accordingly, it has focused on binarisms such as technical versus non-technical writing, exposition versus narration-an understandable strategy for an emerging discipline struggling for identity, recognition, and autonomy, but hardly one conducive to perceiving the value of shared features such as narration. Ironically, familiarity with the work of narratologists provides a limited antidote in this situation for, however insightful they may be in their own disciplines, they are curiously myopic in their denial of narration in technical communication (e.g., Mink or White).

\section{The Complexity and Pervasiveness of Narration in Technical Communication}

But whatever the reasons, our devaluation of narration is unwarranted in light of the complexity and pervasiveness of narration in technical communication. 


\section{Complexity of Narration}

First, consider complexity. For example, one of the key issues in narrative theory is the relation between fabula and sujet, between the order of occurrence of events in time and the order of their presentation in discourse. Insisting on the complexity of the relation between fabula and sujet, Gérard Genette notes "the characteristic effect of anachrony" in Western literary tradition (36; emphasis added). For Genette, then, violations of chronology are the norm rather than the exception.

For technical-communication instructors, on the other hand, the relation between fabula and sujet is non-problematical: Narration involves a simple linear sequence of events, the easiest mode, therefore, for students to execute (e.g., Fishman 28). But the anachrony of which Genette speaks is, in fact, characteristic of technicalcommunication texts as well. In her study, Mary Lay in effect documents the intricacies of the relation between fabula and sujet in an account of the Three-Mile-Island incident in Physics Today. Concludes Lay: " ... students should understand that seldom does straight chronological order give the most meaningful account of an event or operation" (158). As her analysis suggests, devaluation of narrative on the basis of felt simplicity is unwarranted.

\section{Pervasiveness of Narration}

The devaluation of narrative is also unwarranted in light of the pervasiveness of narration in technical discourse. Clearly, most of us find narrativity in histories of science and technology, and in progress reports, process descriptions, procedure outlines, and instructional or "how-to" manuals. We all also recognize the narrativity of "organizational stories" and the many legends told widely about the "giants" of science and technology. These legends, for example, serve in conveying the attitudinal and methodological themata of enterprises, themata such as optimism (through the story of Einstein's math failures as a student), diligence (through the story of Edison's dogged search for a filamentary material for his incandescent lamp), care (through the story of the meticulous measurements of the velocity of light by Michelson and Morley), and analogy (through the story of Newton's conception of gravitational attraction after an apple fell on his head).

But narrativity extends far beyond such obvious cases. Indeed, we can only suggest the pervasiveness of, and our great dependence on, narrativity in scientific and technical communication.

\section{Narrative in Written and Oral Texts}

At an encompassing level are the master narratives that govern the scientific and technical enterprises, and affect institutional values. Master narratives determine the very way research is conducted: Witness the myth of the unique, inexorable scientific method. They underlie the way scientists think about their disciplines: As anthro- 
pologist Misia Landau argues, "scientific theories are essentially narrative" (262). Master narratives also underlie the institutions that regulate science and technology: Who is unaware of the IBM epic or the Bell Labs saga (Rodgers)? They underlie the editorial policies of scientific- and technical-publication organs. Thus, a publication's articles in a given subject area may follow a common narrative thread: For decades, according to Jeffrey Marsh, the doctrine of mutually assured destruction underlay every article on nuclear policy published in Scientific American.

At an intermediate level in scope, one finds narrativity in such discourse genres as the scientific or technical article. Singling out the scientific articles for attention, sociologist Joseph Gusfield reviews 45 "research papers on the issue of drinking and driving, treating the scientific document as a literary, artistic product" (16). In his analysis of a representative paper, he finds narrative form, and a particular kind at that. Drawing from Northrup Frye's taxonomy of narrative modes of emplotment-tragedy, comedy, romance, and satire-Gusfield labels as tragic the story that shifts the focus of medical attention and enforcement policies from "social drinkers" to "problem drinkers" (29). His identification of a tragic mode of emplotment stems from his focus on the fate of the actants, or research subjects, discussed in the article. With focus, however, on the fate of the researcher as implied protagonist, the story is best seen as a romance-as a quest (for "truth") in which obstacles (or "ignorance") are overcome and the hero emerges triumphant (or "more knowledgeable"). The story, then, is not tragic, for science is, as Michael Serres so brilliantly argues, "an infinite game in which we always win" (22). Thomas Edison would agree. When asked if he were not discouraged after countless "failures" in his search for a filamentary material for the incandescent lamp, he replied "No-I knew 10000 things that do not work."

Also at an intermediate level are such projective scientific texts as scenarios, scripts, frames, simulations, games, case studies, and "what-if" or "worst-case" analyses. These texts often involve accounts of event sequences associated with plausible humanbehavioral patterns in given contexts. The texts frequently take the form of flexible plots - that is, "slotted" narratives with optional event sequences-that are provided with concretes, or specifics, only at instantiation. Such narrative structures are proliferating in current research and development related to computer-based systems for knowledge representation, e.g., for decision support and artificial intelligence.

At a lower level still are the equations of science and technology, which may be regarded as highly condensed narratives. Such an interpretation is manifest in the case of "story problems," where reduction of a story to a soluble set of equations is a central issue. Consider, too, the "quantitative laws" (Kyburg) of science, e.g., Ohm's or Boyle's Law, that are expressed in equations and subject to experimental verification or refutation. These equations, ubiquitous in both science and technology, are "shorthand" representa- 
tions whose meanings depend on procedural descriptions incorporating tacit knowledge-descriptions that, as we have noted, are widely regarded as narrational.

Moreover, even if we restrict attention to the level of symbolism, we find that rule-governed procedures are essential for interpretating equations. Consider, for example, the evaluation of $x$ in the equation

$$
x=a \times b+c / d
$$

for given values of $a, b, c$, and $d$. Lacking interpretive rules, we are unsure whether $a \times b+c$, or only $c$, is divided by $d$. Under a typical "precedence rule," the division operation is performed first and the addition operation last, so we know that our final possible interpretation is "correct." Thus, $c / d$ is evaluated first, then $a \times b$, after which these results are added to obtain the value of $x$. Interestingly, the given precedence rule leads to an evaluation procedure that does not follow the linear order of the equation's transcription. Viewed in terms of narrative theory, this disparity exemplifies the characteristic anachrony between fabula and sujet mentioned earlier.

At the lowest level considered here, narrativity may be found in the "things" and concepts associated with science and technology. In "Things are Stories," Eugene Bar contends that objects and concepts are linked reflexively with internal schemata governing human actions. Thus, these objects and concepts are constituted as such by being assimilated in action schemata and are apprehended only insofar as they evoke these schemata. Citing as an example Nietzsche's "critique of the concept 'movement,' as used in classical physics," Bar shows that "it involves sensory schemata of something which is moved, i.e., a subject-object schema, an actor-act-acted-upon schema, a cause-effect schema" (199). Moreover, in light of the narrativity widely imputed to procedural or operational descriptions, Bar's notion of concepts as stories seems compatible with Percy Bridgman's notion of "operational definitions" for the fundamental concepts of physics. According to Bridgman, "we mean by any concept nothing more than a set of operations; the concept is synonymous with the corresponding set of operations" (5).

\section{Narrative in Visuals}

But narrative is found not only in written and oral texts; it occurs in visuals as well. For despite the popular view that visual-in contrast to verbal-texts are comprehended holistically, that is, taken in at a glance, the interpretation of visuals involves more often than not the construction of a plausible narrative. We take a case other than the flowcharts and circuit diagrams already acknowledged as narrational in the literature: Consider Gerald Holton's analysis of a physicist's interpretation of a bubble-chamber photograph in a technical report:

... the [interpretation] of a bubble-chamber photograph is cast largely in terms of a life-cycle story. It is a story of evolution and devolution, of 
birth, adventures, and death. Particles enter on the scene, encounter others, and produce a first generation of particles that subsequently decay, giving rise to a second and perhaps a third generation. They are characterized by relatively short or relatively long lives, by membership in families or species (Scientific Imagination 17).

The narrativity of the visual interpreted is clear. Moreover, Holton suggests that narrativity is not atypical in scientific and technical visuals (Thematic Origins).

\section{The Potential Advantages of Narration in Technical Communication}

To recognize that narration in technical communication is more complex and pervasive than our literature suggests is, however, not enough. Narration will be valued in technical communication only if we appreciate its potential advantages. What, then, are the potential advantages of narration?

\section{General Advantages}

Viewed broadly, the literature suggests general advantages that should intrigue the technical communicator: Experimental studies suggest that narrative, as opposed to expository, texts are read faster (Graesser, Hoffman, and Clark), processed more effectively (Britton), and remembered better (Thorndyke; Graesser, HauptSmith, Cohen, and Pyles). Michael McGuire argues that narrative texts are more believable and persuasive than exposition; their greater rhetorical power stems from the fact that they are "more concrete and more easily grasped than universals" (134). The compelling power of the concrete over the abstract and the link of the former to narrative are shown in experiments reported by Nisbett, et al. Perhaps their illustration makes the point more eloquently than the writeup of their experiment and is worth quoting in full:

Let us suppose that you wish to buy a new car and have decided that on the grounds of economy and longevity you want to purchase one of those solid, stalwart, middle class Swedish cars-either a Volvo or a Saab. As a prudent and sensible buyer, you go to Consumer Reports, which informs you that the consensus of their experts is that the Volvo is mechanically superior, and the consensus of the readership is that the Volvo has the better repair record. Armed with this information, you decide to go and strike a bargain with the Volvo dealer before the week is out. In the interim, however, you go to a cocktail party where you announce this intention to an acquaintance. He reacts with disbelief and alarm: "A Volvo! You've got to be kidding. My brother-in-law had a Volvo. First, that fancy fuel injection computer thing went out. 250 bucks. Next he started having trouble with his rear end. Had to replace it. Then the transmission and the clutch. Finally sold it in three years for junk." The logical status of this information is that the $\mathrm{N}$ of several hundred Volvo-owning Consumer Reports' readers has been increased by one, and the mean fre- 
quency of repair record shifted by an iota on three or four dimensions. However, anyone who maintains that he would reduce the encounter to such a net informational effect is either disingenuous or lacking in the most elemental self-knowledge. (129)

\section{Assistance in Solving Problems}

Such general advantages aside, narration will be truly valued only if it helps us perceive and solve problems we couldn't, or didn't, address before. Consider a chronic problem, a problem encapsulated in the expression "two-cultures syndrome." Noting the everwidening communication gap between "specialist" and "ordinary citizen," and the failure of classical rhetoric to bridge this gap, S. Michael Halloran calls for a new rhetorical focus on the "fundamental problem of why the gap between the [specialist's] and [ordinary citizen's] world is so broad and how one might bridge it successfully" (625). For social scientists, according to Martin Rein, narration provides the new focus called for by Halloran. Rein advocates a new role for social scientists involved in formulating public policy:

The giving of advice and the design of social programmes [should be] like the telling of relevant stories ... [to] provide an interpretation of a complex pattern of events with normative implications for action, and not with a universal law. (266)

Similarly, for scientists and technologists, rhetorician Walter Fisher advocates narration in "public moral argument." Noting the failure of rational discourse in the nuclear-war debate, for example, Fisher argues that the traditional rational mode is an acquired elitist skill "relevant only in specialized fields," whereas the narrative mode is a skill possessed by all and is, therefore, relevant in the society at large. Employing a universal mode such as narrative should, according to Fisher, foster identification and reconciliation rather than the alienation and polarization characteristic of the nuclearwar debate to date.

Thus, both Rein and Fisher view narration as a valuable alternative to rational discourse in reconciling conflicting perspectives in the public arena. But communication between laity and expert does not fail because of a conflict between modes of discourse, one narrational and the other non-narrational, for both discourses are ultimately narrational; rather, communication may fail because different modes of narrative emplotment are used. Thus, the expert generally imports a romantic emplotment, the mode we have shown to be characteristic of the technical reports and articles privileged in the expert's discipline; on the other hand, in an era of increasing disenchantment over the impact of science and technology, the lay communicant characteristically adopts a tragic emplotment. Communication attempts across such incommensurate modes of narrative emplotment may be foredoomed, as suggested by Hayden White's study of theory acceptance across different prefigurative modes in history (Metahistory 430). 
Moreover, the public arena is not the only place where a technical professional encounters such conflicting perspectives; they are also encountered in more typical working contexts, i.e., within organizations. For the old view of organizations as monoliths, with commonality and convergence of goals, is now largely discredited in the literature of organizational science (e.g., Pfeffer or Keen). One finds, rather, an increasing recognition of pluralism in organizations, of politically-based coalitions with competing goals, and a recognition as well of the need for new communication models to foster negotiation and compromise in these competitive situations (Barton and Barton, "Communication Models" 1984).

Narrative seems a promising candidate: Noting that "stories are so central to organizations that not only do organizations depend on them, but stronger still, they couldn't function without them," Ian Mitroff and Ralph Kilmann go further and use storytelling as a formal basis for resolution of intra-organizational conflict and as an alternative heuristic to traditional methods for problem solving (18). In particular, the disparate stories of ideal organizations told by managers with different (Jungian) personality types help promote tolerance of alternate corporate models, goals, and plans.

Narrative also serves in reconciling the perspective of an organization with that of its employees. Joanne Martin points out the superiority of the story over traditional exposition in acculturating employees:

In attempting to communicate information about organizational culture, beliefs about process, management philosophy, and some organizational policies, organizational representatives often find explicit forms of communication ineffective.... Organizational representatives usually resolve this problem by relying on implicit, often symbolic, forms of communication .... The most common form of implicit communication ... is the story. $(260-61)$

\section{Conclusion}

Thus, the potential benefits of narration do not derive only from the enhanced use of traditional storytelling when perspectives conflict, for the perspectives bridged in technical communication are not necessarily always conflicting. Perspectives are, nevertheless, always disparate, and varying degrees of disparity may call for differing degrees, levels, and modes of narrativity. In short, given the pervasiveness of narration in technical communication, its principal potential benefits will not accrue simply from its greater use in boundary cases, i.e., in cases involving conflict. Rather, we need research aimed at a more conscious and informed exploitation of narration in technical communication, at the use of narration appropriate at a variety of levels throughout technical discourse in given contexts and with given goals. But that is another story, a story to be told at another time, in another place.... 


\section{References}

Bal, Mieke. Narratology: Introduction to the Theory of Narrative. Trans. Christine van Boheemen. Toronto: U of Toronto P, 1985.

Bar, Eugene. "Things are Stories: A Manifesto for a Reflective Semiotics." Semiotica 25.3/4 (1979): 193-205.

Barthes, Roland. "Introduction to the Structural Analysis of Narrative." Image, Music, Text. Trans. Stephen Heath. New York: Hill and Wang, 1977. 79-124.

Barton, Ben F., and Marthalee S. Barton. "Communication Models for Computer-Mediated Information Systems." Journal of Technical Writing and Communication 14.4 (1984): 289-306.

"What is Technical Writing? Prolegomenon to a Contextual Definition." Technical Communication: Perspectives for the Eighties. NASA Conference Publication 2203: Part 1. Ed. J. C. Mathes and Thomas E. Pinelli. Washington: NASA, 1981. 3-14.

Bridgman, Percy. The Logic of Modern Physics. New York: Macmillan, 1955.

Britton, Bruce K., Arthur C. Graesser, Shawn M. Glynn, Tom Hamilton, and Margaret Penland. "Use of Cognitive Capacity in Reading: Effects of Some Content Features of Text." Discourse Processes 6.1 (1983): 39-57.

Brooks, Peter. "Fictions of the Wolfman." Diacritics 9.1 (1979): 72-81.

Culler, Jonathan. "Literary Theory in the Graduate Program." The Pursuit of Signs: Semiotics, Literature, Deconstruction. Ithaca: Cornell UP, 1981. 210-26.

"Problems in the Theory of Fiction." Diacritics 14.1 (1984): 2-11.

Derrida, Jacques. Marges de la philosophie. Paris: Minuit, 1972.

Fisher, Walter R. "Narration as a Human Communication Paradigm: The Case of Public Moral Argument." Communication Monographs 51.1 (1984): 1-24.

Fishman, Judith. "Enclosures: The Narrative within Autobiography." Journal of Advanced Composition 2.1/2 (1981): 23-30.

Frye, Northrup. The Anatomy of Criticism: Four Essays. Princeton: Princeton UP, 1957.

Gallie, W. B. Philosophy and Historical Understanding. London: Chatto and Windus, 1964.

Genette, Gérard. Narrative Discourse: An Essay in Method. Trans. Jane E. Lewin. Ithaca: Cornell UP, 1980.

Graesser, Arthur C., K. Haupt-Smith, A. D. Cohen, and L. D. Pyles. "Advanced Outlines, Familiarity, Text Genre and Retention of Prose." Journal of Experimental Education 48.4 (1980): 281-90.

Graesser, Arthur C., Nicholas L. Hoffman, and Leslie F. Clark. "Structural Components of Reading Time." Journal of Verbal Learning and Verbal Behavior 19.2 (1980): 135-51.

Gusfield, Joseph. "The Literary Rhetoric of Science: Comedy and Pathos in Drinking Driver Research." American Sociological Review 41.1 (1976): 16-34.

Halloran, S. Michael. "On the End of Rhetoric, Classical and Modern." College English 36.6 (1975): 621-31.

Hardy, Barbara. "Towards a Poetics of Fiction: An Approach Through Narrative." Novel 2.1 (1968): 5-14. 
Holton, Gerald. Thematic Origins of Scientific Thought: Kepler to Einstein. Cambridge: Harvard UP, 1973.

The Scientific Imagination: Case Studies. Cambridge: Cambridge UP, 1978.

Keen, Peter G. W. "Information Systems and Organizational Change." Communication of the ACM 24.1 (1981): 24-33.

Kermode, Frank. The Sense of an Ending. New York: Oxford UP, 1967.

Kuhn, Thomas S. The Essential Tension: Selected Studies in Scientific Tradition and Change. Chicago: U of Chicago P, 1977.

Kyburg, Henry E., Jr. "The Confirmation of Quantitative Laws." Philosophy of Science 52.1 (1985): 1-22.

Landau, Misia. "Human Evolution as Narrative." American Scientist 7.2 (1984): 262-68.

Lay, Mary M. "Teaching Narrative in Technical Writing Courses." The Technical Writing Teacher 9.3 (1982): 156-58.

MacIntyre, Alisdair. After Virtue: A Study in Moral Theory. Notre Dame: U of Notre Dame P, 1981.

Marsh, Jeffrey. "Politicizing Science." Commentary Mar. 1984: 51-53.

Martin, Joanne. "Stories and Scripts in Organizational Settings." Cognitive Social Psychology. Ed. Albert Hastdorf and Alice Isen. New York: Elsevier/North-Holland, 1982. 255-305.

McCloskey, Donald N. "The Literary Character of Economics." Daedalus 113.3 (1984): 97-119.

McQuire, Michael. "Some Problems with Rhetorical Example." PRE/ TEXT 3.2 (1982): 121-36.

Mink, Louis O. "History and Fiction as Modes of Comprehension." New Directions in Literary History. Ed. Ralph Cohen. Baltimore: Johns Hopkins UP, 1974: 107-24.

Mitchell, W. J. T., ed. On Narrative. Chicago: U of Chicago P, 1981.

Mitroff, Ian I., and Ralph H. Kilmann. "Stories Managers Tell: A New Tool for Organizational Problem Solving." Management Review 64.7 (1975): 18-28.

Nisbet, Robert. Sociology as an Art Form. London: Oxford UP, 1976.

Nisbett, Richard E., Eugene Bordiga, Rick Crandall, and Harvey Reed. "Popular Induction: Information Is Not Necessarily Informative." Cognition and Social Behavior. Ed. John S. Carroll and John W. Payne. Hillsdale: Erlbaum, 1976. 113-33.

Peters, Thomas J., and Robert H. Waterman, Jr. In Search of Excellence: Lessons from America's Best Run Companies. New York: Warner Books, 1982.

Pfeffer, Jeffrey. Organizational Design. Arlington Heights: AHM Publications Corp., 1978.

Prince, Gerald. Narratology: The Form and Functioning of Narrative. Berlin: Mouton, 1982.

Rein, Martin. Social Science and Public Policy. New York: Penguin Books, 1976.

Rodgers, William. THINK: A Biography of the Watsons and IBM. New York: Stein and Day, 1969.

Schafer, Roy. "Narration in the Psychoanalytic Dialogue." On Narration. Ed. W. J. T. Mitchell. Chicago: U of Chicago P, 1981. 25-49. 
"On Becoming an Analyst of One Persuasion or Another." Contemporary Psychoanalysis 15.3 (1979): 345-60.

Serres, Michel. "Knowledge in the Classical Age: La Fontaine to Descartes." Hermes: Literature, Science, Philosophy. Ed. Josué Harari and David Bell. Baltimore: Johns Hopkins UP, 1982. 15-28.

Smith, Barbara Herrnstein. "Narrative Versions, Narrative Theories." American Criticism in the Poststructuralist Age. Ed. Ira Konigsberg. Ann Arbor: U of Michigan P, 1981. 162-86.

Thorndyke, P. W. "Cognitive Structures in Comprehension and Memory of Narrative Discourse." Cognitive Psychology 9.1 (1977): 77-110.

Turner, Victor. "Social Dramas and Stories About Them." On Narration. Ed. W. J. T. Mitchell. Chicago: U of Chicago P, 1981. 137-64.

Watson, James D. The Double Helix: A Personal Account of the Discovery of the Structure of DNA. Ed. Gunther S. Stent. New York: Norton, 1980.

White, Hayden. Metahistory: The Historical Imagination in NineteenthCentury Europe. Baltimore: Johns Hopkins UP, 1973.

Yeazell, Stephen C. "Convention, Fiction and Law." New Literary History 8.1 (1981): 88-102.

CALL FOR PAPERS

1988 MLA Sessions Sponsored by ATTW

Topic I (pedagogical session): Humanistic Texts in the Technical-Writing Class: The Uses of Literary Fiction and Non-Fiction

What role can literary fiction and non-fiction play in the technical-writing course? In what ways can teachers use fiction and non-fiction to teach technical writing? What are the connections between literary discourse and technical discourse, and how can these connections be used in technical-writing courses? Is there anything "literary" about technical discourse? Should technical writing and the study of literature be integrated into an academic program? If so, how and to what ends?

Topic II (theoretical session): Ethics and Technical Communication

What are the predominant ethical issues that face technical communicators and/or teachers of technical communication? What are the theoretical and historical foundations of our conceptions of ethics as they apply to technical communication? How do the ethical concerns of other disciplines bear upon our conceptions of ethics in technical communication? Can/ should teachers of technical communication include the study of ethics in their courses?

Send two copies of a detailed, two-page proposal for either panel, by January 15, 1988, to Stephen Doheny-Farina, English Department, UNCC, Charlotte, North Carolina 28223. 